\title{
ANALYSES OF PLANT PRODUCTS IN GREATER DETAIL
}

\author{
L. Paloheimo, K. A. Vainio, M.-L. Kero, and Eine Herkola \\ Department of Animal Husbandry, University of Helsinki
}

Received December 22, 1960

According to the customary Weende system food constituents are divided into 6 fractions: water, ash, crude fat, crude protein, crude fibre, and nitrogen free extract. This fractionation is, however, biologically very defective and even misleading (2, p. 16). Especially the dividing of the group of crude carbohydrates $(\mathrm{N}$ - and lipidfree organic matter) into crude fibre and $\mathrm{N}$-free extract is quite unbiological; e.g. the main part of the lignin falls into the $\mathrm{N}$-free extract together with starch and sugars.

At this institute Paloheimo and Paloheimo (3, p. 1) have developed a method for a determination of the total of vegetable membrane subtances. When this fraction, together with the crude protein and crude fat, is subtracted from the organic matter, a fraction is obtained which we call valuable crude carbohydrates or simply valuable carbohydrates. This fraction contains besides starch, fructosans, and sugars, the main part of pectins. But it also contains some noncarbohydrate substances such as vegetable acids.

We have further tried to fractionate the group of membrane substances determining cellulose, lignin and pentosans. The sum of the percentages of these substances is, however, usually somewhat smaller than the percentage of the membrane substances and thus we have had to enclose another fraction: other membrane substances. For the purpose of characterizing the quality of the investigated materials also in the conventional way, the crude fibre has been determined.

\section{Methods}

1. The drying of the materals. - The materials are dried in a vacuum oven at $70^{\circ} \mathrm{C}$.

2. A s h. - Incineration at $700^{\circ} \mathrm{C}$.

3. Crude protein. - Nitrogen determination according to Kjeldahl. Crude protein factor 6.25 .

4. $\mathrm{Crude}$ fat. - The sample is shaken with water in room teperature, filtered, dried, and extracted with benzene-ethanol. 
5. M e m b r a n e substan c e s. - According to the method of Palohermo and Palohermo (l.c). The main principle of the method is boiling the sample with 0.05 normal hydrochloric acid.

6. The valuable crude carbohydrates. - The percentages of crude fat, crude protein, and membrane substances are subtracted from the percentage of the organic matter.

7. Ce $11 \mathrm{ulos}$ e. - The method used will be described in detail in the near future. The main principle: shaking the sample with 3 normal $\mathrm{NaOH}$ solution in closed bottles in a boiling water bath. Corrections for pentosans and crude lignin.

8. P e n t o s a n s. - For this determination the residue obtained by the boiling of the sample in 0.05 normal $\mathrm{HCl}$ solution is used (see paragraph 5 ). The determination is made according to the Tollens principle. Modification according to the Official Methods of Analysis (p. 376).

9. Lig n in. - The method used has been described by SALO (4, p. 187). Prehydrolysis is used; the main hydrolysis by 72 pct. $\mathrm{H}_{2} \mathrm{SO}_{4}$; protein correction.

10. Other membrane substan ces. - The percentages of cellulose, pentosans, and lignin are subtracted from the percentage of the membrane substances.

\section{Results and discussion}

The results obtained by the above mentioned system of analysis are shown in Table 1. In Table 2 we have calculated for some of the materials the composition of the fraction "membrane substances" as percentages of this fraction.

As the ash obtained by incineration is not a natural plant component and as it contains oxides and carbonates it is obvious that the unavoidable incorrectness of the ash determination results in figures too low for the valuable carbohydrates.

The crude fat contains some nitrogen. This fragment of $\mathrm{N}$ multiplied by 6.25 will erroneously raise the crude protein percentage.

The conventional protein factor is too low in cases where the protein contains bigger prosthetic groups poor in nitrogen. The omitting of these fragments, i.e. the prosthetic groups, in the crude protein determination, increases the figures of valuable carbohydrates, which however, results in a more correct conception of the nutritional nature of the material in question.

Although the acid solution used in the determination of the membrane substance fraction is greatly diluted, some of the cell wall constituents are dissolved and will thus be incorporated with the fraction of valuable carbohydrates. It is, however, possible that these easily hydrolysable carbohydrates may be digested even in the alimentary canal of animals with a simple digestive tract. This concerns especially the pectins which, according to our investigations, dissolve by the 0.05 normal acid. Thus the fact that the most readily hydrolysable cell wall constituents will be incorporated with the valuable carbohydrates may not seriously affect the method used. As one part of the valuable carbohydrates is an extract of the cell walls it is questionable if the term membrane substances is a proper name for the fraction obtained by boiling in 0.05 normal acid. Perhaps "fibre substances» would be a more 
อมq! әрกхว

səourąsqns әиยม Іәчзо

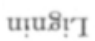

suesozuad

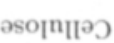

sәzемрќ

-oqses

әчеп्ए $e_{\Lambda}$

saouezsqus วurıquวग

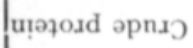

7еу әрпхว

usy

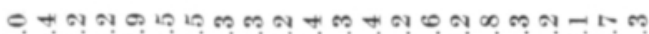

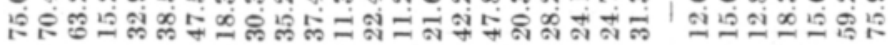

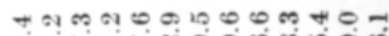

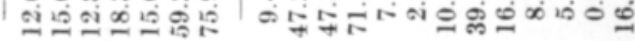

๑ ம

t

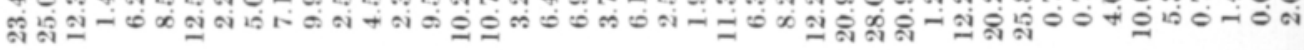

ex n

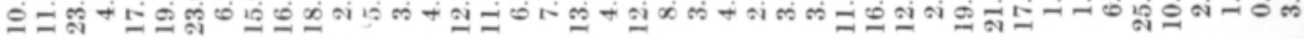

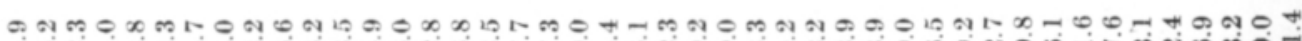
பำ

0 onแ่ ब а

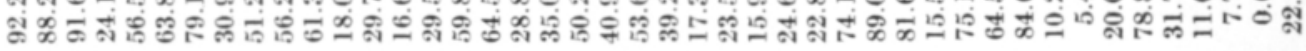

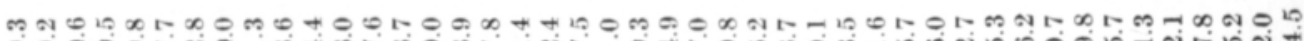
ดององ 는

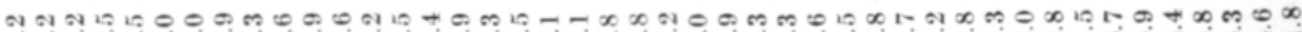

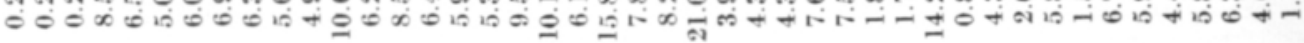

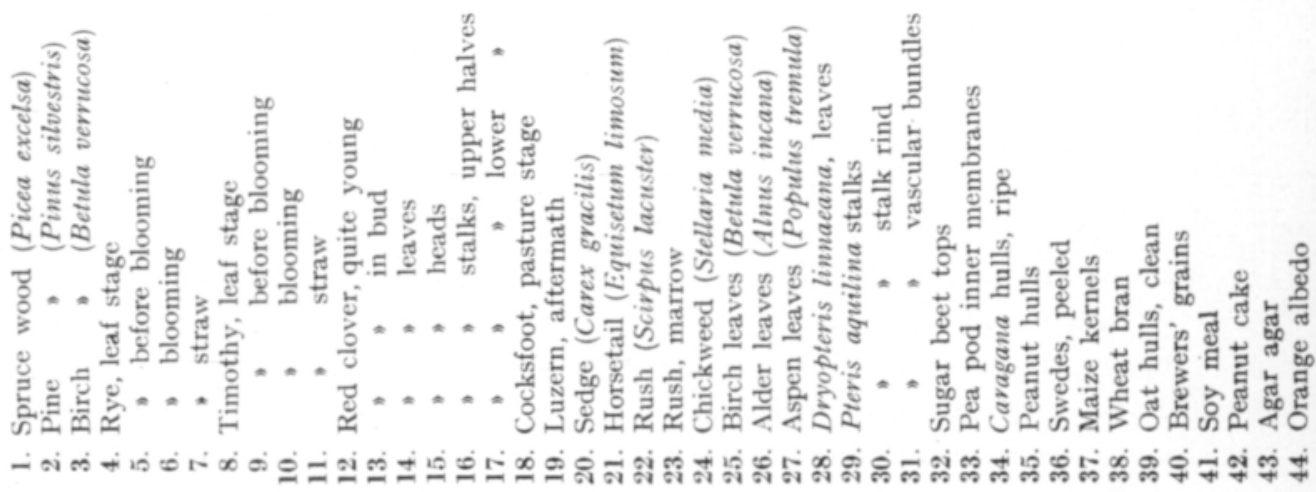


Table 2. The composition of the fraction Membrane Substances in some vegetable materials. (Per cent of the fraction Membrane Substances).

\begin{tabular}{|c|c|c|c|c|}
\hline & Cellulose & Pentosans & Lignin & $\begin{array}{c}\text { Other } \\
\text { membrane } \\
\text { substances }\end{array}$ \\
\hline Spruce wood & 59.5 & 11.8 & 25.4 & 3.3 \\
\hline Birch wood & 46.1 & 25.3 & 13.5 & 15.1 \\
\hline Rye, leaf stage & 45.8 & 17.1 & 5.7 & 31.4 \\
\hline Rye, straw & 43.9 & 29.1 & 15.9 & 11.1 \\
\hline Timothy, leaf stage & 45.4 & 22.3 & 7.2 & 25.1 \\
\hline Timothy straw & 46.0 & 30.5 & 16.1 & 7.4 \\
\hline Red clover leaves & 35.8 & 18.3 & 13.9 & 32.0 \\
\hline Red clover stalks, lower halves & 44.3 & 17.8 & 16.6 & 21.3 \\
\hline Sedge & 37.8 & 27.4 & 13.7 & 21.1 \\
\hline Horsetail & 59.7 & 10.0 & 9.0 & 21.3 \\
\hline Rush & 48.8 & 23.2 & 11.3 & 16.7 \\
\hline Pteris aquilina stalks & 45.8 & 16.1 & 28.2 & 9.9 \\
\hline Sugar beet tops & 41.6 & 15.1 & 7.7 & 35.6 \\
\hline Peanut hulls & 35.3 & 20.9 & 30.5 & 13.3 \\
\hline Swedes, peeled & 59.7 & 14.0 & 6.5 & 19.8 \\
\hline Maize kernels & 29.6 & 31.5 & 13.0 & 25.9 \\
\hline Wheat bran & 38.0 & 33.0 & 20.0 & 9.0 \\
\hline Oat hulls & 42.0 & 32.9 & 13.5 & 11.6 \\
\hline Soy meal & 59.5 & 17.2 & 6.0 & 17.3 \\
\hline Organge albedo & 51.1 & 17.0 & 9.0 & 22.9 \\
\hline
\end{tabular}

accurate term. As, however, the latter term can be mistaken for the crude fibre, we have preferred not to use it. On the other hand the fraction membrane substances, as understood in this paper, is not very conventional. The investigations of PALOheimo and Paloheimo (l.c.) have shown that the doubling of either the acid concentration or the boiling time has only a minor influence on the results obtained. In most cases the mere boiling in water results in figures which are only very slightly bigger than those obtained by boiling in 0.05 normal acid.

The fraction valuable carbohydrates, or rather, the valuable crude carbohydrates, contains in the first place all the cell enclosure carbohydrates. As to the criticism concerning this fraction we refer to the previous paragraphs.

The cellulose determination method used in this investigation is intended as a method for true cellulose.

As the pentosans are determined from the residue obtained by boiling with 0.05 normal acid, this fraction in our analysis scheme can not contain any furfurol producing substances belonging to the cell enclosure. On the other hand some very easily hydrolysable cell wall pentosans are possibly omitted from this fraction. Further one must consider that the heading "Pentosans" is not a strictly biological conception because pentose anhydrides can be connected with other sugar anhydrides forming different hexopentosans or uronic acid compounds. If so, the hexosan or uronic acid moiety of the molecules will be connected to the nother membrane substances." 
In cases where the lignin content of the material is low the use of the conventional crude protein factor (6.25) in the protein correction may cause erroneous results for lignin.

The fraction "other membrane substances" contains mainly cell wall hemicelluloses other than pentosans.

As for the results of the analyses only some of the more notable details will be pointed out below. Table 1 shows that the ash content in Stellaria media $(21.0 \%)$, horse tail $(15.8 \%)$, and sugar beet tops $(14.2 \%)$ is especially high. As the samples in question were very clean the ash obtained must belong to the plant proper. The membrane substance content in the woods (88.2-92.2\%) is higher than in all other materials excepting the stalk rind of the fern Pteris aquilina $(89.0 \%)$ which contains more membrane substances than pine wood $(88.2 \%)$. Also the rye straw $(79.1 \%)$, pea pod inner membranes $(75.1 \%)$, peanut hulls $(84.6 \%)$, and oat hulls $(78.8 \%)$ have a very high percentage of membrane substances. Of the investigated materials peanut hulls contain the lowest percentage of valuable carbohydrates $(4.8 \%)$. Then follow the woods $(5.6-5.8 \%), P$. aquilina stalk rind $(6.1 \%)$, and rye straw $(8.1 \%)$. Especially large is this fraction in maize kernels $(78.3 \%)$, peeled swedes $(71.6 \%)$, orange albedo $(68.9 \%)$, and agar agar $(91.7 \%)$. In the two latter materials the valuable carbohydrates evidently contain mostly pectins and readily hydrolysable hemicelluloses. Besides the woods $(42.3-54.9 \%)$ rye straw $(34.7 \%)$, Pteris aquilina stalks $(33.9 \%)$ and their different parts $(38.9,39.0 \%)$, pea pod inner membranes $(30.2 \%)$, oat hulls $(33.1 \%)$, and peanut hulls $(29.8 \%)$ have an especially high content of cellulose. A high pentosan content is found in birch wood $(23.2 \%)$, rye straw $(23.0 \%)$, and oat hulls $(25.9 \%)$. The lignin content is highest in the rind of $P$. aquilina stalks $(28.0 \%)$. Also peanut hulls $(25.8 \%)$ contain more lignin than soft woods (spruce $23.4 \%$ and pine $25.0 \%$ ). The percentages of the other membrane substances are in most cases less than 10 .

Table 2 shows that, excepting the maize kernels, in all materials included in the Table cellulose is the main component in the fraction membrane substances. Its share is usually above $40 \%$. The share of pentosans does not exceed $33 \%$. The lignin content in membrane substances is highest in peanut hulls $(30.5 \%)$. The content of other membrane substances is most variable. The membrane substances of spruce wood contain only $3.3 \%$ of those substances, the corresponding figure for sugar beet tops being 35.6. One can conclude from the figures in Table 2 that the composition of the cell walls in different materials and evidently in different plant tissues is very variable. From the Table one cannot find two sets of figures which would be nearly equal.

Table 1 shows that in every material the percentage of the crude fibre is higher, and in most instances appreciably higher, than the percentage of cellulose. On the other hand it is always considerably lower than the percentage of membrane substances. If one calculates the percentage of crude fibre in membrane substances it appears that it varies between 50.3 (in oat hulls) and 85.3 (in Pteris aquilina stalk rind). In the sedge and cereal products (maize, wheat bran, oat hulls, and brewers' grains) it is about 50. In spruce and pine wood, luzern, alder leaves, and $P$. aquilina 
stalks the percentage is about 80 . In peanut hulls it is 84.2 . It is difficult to notice any correlation between the ratio of crude fibre in the membrane substances and any other feature of the investigated materials.

\section{S $u m$ mary}

The customary Weende system for food analysis is biologically defective and even misleading. The authors have used an analysis scheme in which the conventional crude fibre determination is replaced by the determination of the total of the vegetable cell wall substances. This fraction is called membrane substances. The crude fibre is an arbitrary fragment of this total. E.g. in spruce wood the crude fibre forms about $80 \%$ of the total of the membrane substances, and in wheat bran about $50 \%$. In addition the fraction "membrane substances» is divided into 4 subfractions: cellulose, pentosans, lignin, and other membrane substances. Further, a fraction called valuable carbohydrates is determined by subtracting from 100 the percentages of water, ash, crude protein, crude fat, and membane substances. This scheme has been applied to the investigation of 44 different plant products. A critical examination of the methods used has been included.

R E F E R E C E S

(1) Official Methods of Analysis of the Ass. Off. Agric. Chemists, Washington D. C., 8th ed., 1955: $1-1008$.

(2) Palohemo, Lauri. 1953. Some persistent misconceptions concerning the crude fibre and the nitrogen-free extract. J. Sci. Agric. Soc. Finland 25: 16-22.

(3) Palohermo, L. \& Palohermo, IrJa. 1949. On the estimation of the total of vegetable membrane substances. Ibid 21: 1-16.

(4) SALO, M.-L. 1957. Lignin studies. I. Investigations concerning lignin determination. Ibid 29: $185-$ 193.

S E L O S T S :

TAVALLISTA YKSITYISKOHTAISEMPIA ANALYYSEJ K KASVITUOTTEISTA

L. Paloheimo, K. A. Vainio, M.-L. Kero ja Eine Herkola

Kotieläintieteen laitos, Helsingin Yliopisto

Tavanomainen Weenden rehuanalyysijärjestelmä on bioloogisesti puutteellinen, jopa harhaanjohtavakin. Kirjoittajat ovat käyttäneet analyysijärjestelmää, jossa sovinnainen raakakuitumääritys on korvattu kettoaineiden kokonaispaljouden määrittämisellä. Raakakuitu on mielivaltainen lohko tästä kokonaisuudesta. Kuusipuussa on raakakuidun osuus kettoaineiden kokonaismäärästä n. $80 \%$ ja vehnänleseissä n. $50 \%$. Edelleen on kettoaineiden kokonaismäärä fraktioitu seuraaviin lohkoihin: selluloosa, pentosaanit, ligniini, muut kettoaineet. Aineryhmä, jolle on annettu nimi sarvohiilihydraatit», saadaan vähentämällä 100:sta veden, tuhkan, raakarasvan, raakavalkuaisen ja kettoaineiden prosenttimäärät. Tätä järjestelmää seuraten on tutkittu 44 erilaista kasvituotetta. Kirjoitukseen liittyy myös käytetyn järjestelmän kriitillinen tarkastelu. 